

Asian-Aust. J. Anim. Sci.

Vol. 20, No. 2 : 237 - 244

February 2007

uww.ajasinfo

\title{
Growth, Bone Mineralization and Mineral Excretion in Broiler Starter Chicks Fed Varied Concentrations of Cholecalciferol
}

\author{
S. V. Rama Rao*, M. V. L. N. Raju, G. Shyam Sunder, A. K. Panda and P. Pavani \\ Project Directorate on Poultry, Indian Council of Agricultural Research, Rajendranagar, Hyderabad 500 030, India
}

\begin{abstract}
An experiment was conducted to study the growth performance, bone mineralization and mineral excretion in broiler starter chicks fed high levels of cholecalciferol (CC) at sub-optimal levels of calcium (Ca) and non-phytate phosphorus (NPP). Five hundred and sixty day-old Vencobb female broiler chicks were housed in raised wire floor stainless steel battery brooder pens $(24 " \times 30 " \times 18$ ") at the rate of five chicks per pen. A maize-soyabean meal basal diet was supplemented with dicalcium phosphate, oyster shell powder and synthetic CC to arrive at two levels each of Ca $(0.50$ and $0.60 \%)$, and NPP $(0.25$ and $0.30 \%)$ and four levels of CC $(200,1,200,2,400$ and $3,600 \mathrm{ICU} / \mathrm{kg})$ in a $2 \times 2 \times 4$ factorial design. Each diet was fed ad libitum to chicks in 7 pens from 2 to 21 days of age. Body weight gain, feed intake and bone weight increased $(\mathrm{p}<0.05)$ with increase in level of CC at both the Ca and NPP levels tested. The CC levels required to obtain significant improvement in body weight gain and feed intake reduced (2,400 ICU/kg vs. 1,200 ICU $/ \mathrm{kg})$ with increase in levels of $\mathrm{P}$ in diet $(0.25 \%$ vs. $0.3 \%$, respectively). The feed conversion ratio was significantly improved $(\mathrm{p}<0.05)$ with increase in level of CC from 200 to $1,200 \mathrm{ICU} / \mathrm{kg}$ diet at $0.5 \% \mathrm{Ca}$, while at $0.6 \% \mathrm{Ca}$, the level of $\mathrm{CC}$ in diet did not influence the feed efficiency. Tibia mineralization (density, breaking strength and ash content) and $\mathrm{Ca}$ and $\mathrm{P}$ contents in serum increased significantly $(\mathrm{p}<0.05)$ with increase in levels of CC in diet. The CC effect on these parameters was more pronounced at lower levels of Ca and NPP ( 0.5 and $0.25 \%$, respectively). The data on body weight gain and feed intake indicated that NPP level in diet can be reduced from 0.30 to $0.25 \%$ by increasing CC from 200 to $2,400 \mathrm{ICU} / \mathrm{kg}$. Similarly, the bone mineralization (tibia weight, density and ash content) increased non-linearly $(\mathrm{p}<0.01)$ with increase in CC levels in diet. Concentrations of $\mathrm{P}$ and $\mathrm{Mn}$ in excreta decreased ( $<<0.01)$, by increasing CC level from 200 to $2,400 \mathrm{ICU} / \mathrm{kg}$ diet. It can be concluded that dietary levels of Ca and NPP could be reduced to 0.50 and $0.25 \%$, respectively by enhancing the levels of cholecalciferol from 200 to $2,400 \mathrm{ICU} / \mathrm{kg}$ with out affecting body weight gain, feed efficiency and bone mineralization. Additionally, phosphorus and manganese excretion decreased with increase in levels of CC in broiler diet. (Key Words : Broilers, Cholecalciferol, Calcium, Non-phytate Phosphorus, Bone Mineralization, Mineral Retention)
\end{abstract}

\section{INTRODUCTION}

Environmental pollution from intensive poultry farming is primarily associated with excretion of un-utilized mineral compounds like phytate phosphorus (PP) (Paik, 2000). The phosphoric acid chelates several essential minerals like $\mathrm{Ca}$, $\mathrm{Cu}, \mathrm{Zn}, \mathrm{Fe}$, etc. in cereals and oilseed byproducts (Kornegay et al., 1996), thereby inhibiting their availability to chickens resulting in their excretion into the environment. Cholecalciferol (CC) enhances utilization of PP by increasing synthesis or activity of intestinal phytase (Shafey et al., 1991), increasing phytate hydrolysis (Mohamed et al., 1991; Biehl and Baker, 1997; Qian et al., 1997) and increasing absorption of $\mathrm{Ca}$ and $\mathrm{P}$ (Wasserman and Taylor,

\footnotetext{
* Corresponding Author: S.V. Rama Rao. Tel: +91-40-24017000, Fax: +91-40-24017002, E-mail: svramarao1@rediffmail.com Received November 21, 2005; Accepted March 6, 2006
}

1973; Biehl and Baker, 1997).

The requirement of $\mathrm{CC}$ for broiler chicken fed diets containing adequate levels of $\mathrm{Ca}$ and non-phytate P (NPP) is about 200-500 ICU/kg (NRC, 1994; Baker et al., 1998; Edwards et al., 2002). However, the suggested requirement of CC was higher in diets containing sub-optimal levels of Ca and P (Waldroup et al., 1965; Edwards, 1976; Mc Naughton et al., 1977; Baker et al., 1998). Supplementation of higher levels of CC in layer diet containing adequate levels of $\mathrm{Ca}$ and NPP was reported to enhance the concentration of the vitamin in eggs (Park et al., 2005). The recent literature (Rama Rao et al., 2003a) indicated that the requirements of Ca and NPP for broiler starter chicks were 0.60 and $0.30 \%$, respectively for optimum growth, feed efficiency and mineral utilization at $1,200 \mathrm{ICU} \mathrm{CC} / \mathrm{kg}$ diet. $\mathrm{CC}$ is known to enhance utilization of $\mathrm{Ca}$ and $\mathrm{P}$ in chicken and it is hypothesized that the concentrations of dietary $\mathrm{Ca}$ and NPP can be reduced further by increasing the level of 
Table 1. Composition of basal diet fed to commercial broilers

\begin{tabular}{|c|c|}
\hline Ingredient & $\mathrm{g} / \mathrm{kg}$ \\
\hline Yellow maize & 574.0 \\
\hline Soyabean meal & 390.0 \\
\hline DL-methionine & 1.5 \\
\hline Lysine-HCl & 0.8 \\
\hline Common salt & 4.0 \\
\hline Choline chloride $(50 \%)$ & 1.3 \\
\hline Additives $^{1}$ & 28.4 \\
\hline \multicolumn{2}{|c|}{ Nutrient composition $(\mathrm{g} / \mathrm{kg})$} \\
\hline $\mathrm{ME}\left(\mathrm{kcal} / \mathrm{kg}^{2}\right)$ & 2,875 \\
\hline Crude protein & 231.0 \\
\hline Calcium & 1.59 \\
\hline $\mathrm{NPP}^{2}$ & 0.95 \\
\hline Lysine & 11.10 \\
\hline Methionine & 4.77 \\
\hline \multicolumn{2}{|c|}{$\begin{array}{l}{ }^{1} \text { Additives contained }\left(/ \mathrm{kg}^{-1}\right): \mathrm{Zn}=60 \mathrm{mg} ; \mathrm{Mn}=55 \mathrm{mg} ; \mathrm{Fe}=38 \mathrm{mg} ; \mathrm{Cu}= \\
4 \mathrm{mg} \text {; thiamin }=1 \mathrm{mg} ; \text { pyridoxine }=2 \mathrm{mg} \text {; cyanocobalamine }=0.01 \mathrm{mcg} \text {; } \\
\text { niacin }=1.5 \mathrm{mg} \text {; pantothenic acid }=10 \mathrm{mg} \text {; tocopherol = } 10 \mathrm{mg} \text {; } \\
\text { riboflavin }=10 \mathrm{mg} ; \text { menadione }=2 \mathrm{mg} \text {; retinal acetate = } 1,650 \mathrm{IU} ; \\
\text { monensin sodium }=0.5 \mathrm{mg} \text {. } \\
{ }^{2} \text { Calculated based on the NPP content of individual feed ingredient. }\end{array}$} \\
\hline
\end{tabular}

$\mathrm{CC}$ in diet. Since, the cost (per unit of diet) of synthetic $\mathrm{CC}$ ( $\$ 0.03 /$ ton) is less than that of supplemental $\mathrm{P}$ as dicalcium phosphate ( $\$ 6.67 /$ ton), reducing $\mathrm{P}$ and Ca levels in diet by increasing levels of $\mathrm{CC}$ would reduce the cost of feed considerably besides reducing the $\mathrm{P}$ pollution from the intensive poultry operations. Therefore, in the present study, an attempt was made to study the possibility of reducing dietary levels of $\mathrm{P}$ and $\mathrm{Ca}$ in broiler starter diet by increasing the levels of supplemental $\mathrm{CC}$ in the diet.

\section{MATERIALS AND METHODS}

\section{Birds and management}

Five hundred and sixty commercial day-old Vencobb female broiler chicks were wing banded on day one and randomly distributed into 112-raised wire floor battery brooder pens. The battery brooders were made up of stainless steel in vertical three tire system, in each tire (pen) $(24$ " $\times 30$ " $\times 18$ ") five birds were housed. Each pen was provided with individual linear feeder (1.5 feet) and a plastic waterer (1.5 liter). The bottom of the floor was also made up of stainless steel wire mesh. An excreta tray was fitted under the wire floor to remove the excreta. Battery brooders were placed in an open sided house having optional curtains on both the sides to regulate the in house temperature. The brooder house temperature was maintained at $34 \pm 1^{\circ} \mathrm{C}$ up to $7 \mathrm{~d}$ of age and was gradually reduced to environmental temperature $\left(27\right.$ to $\left.33^{\circ} \mathrm{C}\right)$ by $21 \mathrm{~d}$ of age. Incandescent electrical bulbs were used in the brooders to provide the required temperature and light. Ground maize was provided ad libitum on day one and the respective experimental diets from 2 to $21 \mathrm{~d}$ of age. All the birds were vaccinated with HVT virus (Marek's disease) on day one, Lasota virus (Newcastle disease) on $8^{\text {th }}$ day and infectious bursal disease virus on $15^{\text {th }}$ day to protect them from these diseases.

\section{Diets}

Maize and soyabean meal were analyzed for $\mathrm{Ca}$, total $\mathrm{P}$ (TP) and PP (Haugh and Lantzsch, 1983). Dicalcium phosphate and oyster shell powder were analyzed for $\mathrm{Ca}$ and or P. NPP content in maize and soyabean meal was calculated by subtracting PP from TP. A basal diet was prepared to contain about 2,875 kcal ME (calculated), $23.1 \%$ crude protein, $0.159 \% \mathrm{Ca}$ and $0.095 \%$ NPP (Table 1 ). The basal diet was supplemented with dicalcium phosphate and oyster shell powder to obtain two levels each of $\mathrm{Ca}(0.5$ and $0.60 \%)$ and NPP $(0.25$ and $0.30 \%)$ in a factorial manner. Each combination of $\mathrm{Ca}$ and NPP was supplemented with four levels of CC (200, 1,200, 2,400 and 3,600 ICU/kg diet) in $2 \times 2 \times 4$ factorial design with feed grade crystalline $\mathrm{CC}$ (Duphar Interfran, Mumbai, India). Each experimental diet was assigned at random to 7 battery brooder pens in a completely randomized design and the diets were fed ad libitum from 2 to $21 \mathrm{~d}$ of age.

\section{Traits measured}

Body weight gain and feed intake were recorded at weekly intervals by weighing all the birds in a pen and feed residue on an electronic weighing balance having one $g$ accuracy. Feed conversion ratio was calculated, as feed required producing a unit body weight gain. The degree of leg abnormality was scored as $1=$ normal hock joint; $2=$ slight swelling of hock joint; $3=$ marked swelling of the joint; 4 = marked swelling of the joint and slight slipping of the Achilles tendon and $5=$ marked swelling and complete slipping of the tendon (Watson et al., 1970). Three $\mathrm{ml}$ of blood was drawn from the brachial vein of a bird selected at random from each replicate on $21^{\text {st }}$ day of age. The sera were analyzed for $\mathrm{Ca}$ with an Atomic Absorption Spectrophotometer using $0.1 \%$ lanthanum chloride and inorganic P (Fiske and Subba Row, 1925). Bone mineralization was assessed by measuring tibia weight, density (AG 285 Densitometer, Mettler-Toledo $\mathrm{GmbH}$, Switzerland), breaking strength and ash content. At 22 days of age, seven birds from each treatment were randomly selected and sacrificed by cervical dislocation. Both the tibiae were freed from soft tissue. The dried $\left(100^{\circ} \mathrm{C} / 3 \mathrm{~h}\right)$ bone samples were defattened by extracting with petroleum ether for $48 \mathrm{~h}$. The right tibia of each bird was used to determine the breaking strength (EZ Test, Shimadzu, Japan) with 3-point method, $40 \mathrm{~mm}$ as guage length and $5 \mathrm{~mm}$ velocity of the load cell per minute. Both tibiae of each bird were ashed together at $600 \pm 20^{\circ} \mathrm{C} / 6 \mathrm{~h}$ in a microwave muffle furnace (BR 600521, Phoenix, CEM Corporation, USA). Clean excreta trays were placed under the wire floor 
Table 2. Interaction between dietary levels of calcium (Ca)/non-phytate phosphorus (NPP) and cholecalciferol (CC) on weight gain, feed intake, feed efficiency and tibia weight in broiler chicks (up to $21 \mathrm{~d}$ of age)

\begin{tabular}{|c|c|c|c|c|c|}
\hline $\begin{array}{l}\mathrm{Ca} / \mathrm{NPP} \\
(\%)\end{array}$ & $\begin{array}{c}\mathrm{CC} \\
(\mathrm{ICU} / \mathrm{kg})\end{array}$ & $\begin{array}{l}\text { Weight gain }{ }^{1} \\
\text { (g) }\end{array}$ & $\begin{array}{l}\text { Feed intake }^{T} \\
(\mathrm{~g})\end{array}$ & $\begin{array}{l}\text { Feed conversion ratio } \\
\text { ( } \mathrm{g} \text { feed/g weight gain) }\end{array}$ & $\begin{array}{c}\text { Bone weight }^{1} \\
\text { (g) }\end{array}$ \\
\hline $0.50 / 0.25$ & 200 & $328.7^{\mathrm{d}}$ & $587.8^{\mathrm{c}}$ & $1.727^{\mathrm{ab}}$ & $2.109^{b}$ \\
\hline $0.50 / 0.25$ & 1,200 & $408.6^{\mathrm{b}}$ & $687.6^{\mathrm{b}}$ & $1.630^{\mathrm{d}}$ & $2.254^{\mathrm{ab}}$ \\
\hline $0.50 / 0.25$ & 2,400 & $428.9^{\mathrm{ab}}$ & $735.3^{\mathrm{ab}}$ & $1.661^{\mathrm{cd}}$ & $2.474^{\mathrm{ab}}$ \\
\hline $0.50 / 0.25$ & 3,600 & $449.9^{\mathrm{a}}$ & $770.7^{\mathrm{a}}$ & $1.745^{\mathrm{a}}$ & $2.424^{\mathrm{ab}}$ \\
\hline $0.60 / 0.30$ & 200 & $371.5^{\mathrm{c}}$ & $622.5^{\mathrm{c}}$ & $1.731^{\mathrm{ab}}$ & $2.181^{\mathrm{ab}}$ \\
\hline $0.60 / 0.30$ & 1,200 & $425.0^{\mathrm{ab}}$ & $714.1^{\mathrm{b}}$ & $1.710^{\mathrm{abc}}$ & $2.459^{\mathrm{ab}}$ \\
\hline $0.60 / 0.30$ & 2,400 & $445.0^{\mathrm{ab}}$ & $723.1^{\mathrm{b}}$ & $1.699^{\mathrm{abc}}$ & $2.542^{\mathrm{a}}$ \\
\hline $0.60 / 0.30$ & 3,600 & $431.6^{\mathrm{a}}$ & $733.6^{\mathrm{ab}}$ & $1.675^{\mathrm{bcd}}$ & $2.532^{\mathrm{a}}$ \\
\hline $\operatorname{SEM} \pm$ & & 4.8 & 6.9 & 0.0093 & 0.047 \\
\hline$n$ & & 7 & 7 & 7 & 7 \\
\hline \multicolumn{6}{|c|}{ Mean sum of squares } \\
\hline $\mathrm{Ca}$ & & 1,283 & $9,108^{*}$ & 0.005 & 0.053 \\
\hline NPP & & $5,700^{*}$ & 246 & $0.115^{* *}$ & 0.166 \\
\hline $\mathrm{Ca} \times \mathrm{NPP}$ & & 966 & 49 & $0.039 *$ & 0.008 \\
\hline \multicolumn{6}{|l|}{$\mathrm{CC}$} \\
\hline Linear & & $114,353 * *$ & $298,304 * *$ & 0.002 & 0.055 \\
\hline Non-linear & & $17,030.9^{* *}$ & $26,401 * *$ & $0.0305 * *$ & 0.243 \\
\hline $\mathrm{Ca} \times \mathrm{CC}$ & & 1,754 & 1,527 & $0.028 * *$ & $1.088 * *$ \\
\hline $\mathrm{NPP} \times \mathrm{CC}$ & & $4,378^{*}$ & $7,912 *$ & 0.018 & $0.674 *$ \\
\hline $\mathrm{Ca} \times \mathrm{NPP} \times \mathrm{CC}$ & & 420 & 4,681 & 0.015 & 0.462 \\
\hline Error & & 1,180 & 1,944 & 0.007 & 0.213 \\
\hline
\end{tabular}

$\overline{\mathrm{a}, \mathrm{b}, \mathrm{c}, \mathrm{d}}$ Means having a common superscript in a column do not vary significantly $\left(* * \mathrm{p}<0.01,{ }^{*} \mathrm{p}<0.05\right)$.

${ }^{1} \mathrm{NPP} \times \mathrm{CC} ;{ }^{2} \mathrm{Ca} \times \mathrm{CC}$

of each pen on $20^{\text {th }}$ day of age and the total excreta voided in 24 hours by all five birds was collected from four replicates per treatment to estimate concentrations of $\mathrm{Ca}, \mathrm{P}$ (AOAC, 1990), Fe, Mn. Zn and Cu (Atomic Absorption Spectrophotometer, Perkin Elmer, Analyst 100, Operation Manual).

\section{Statistical analysis}

Three-way factorial analysis was carried out following the Completely Randomized Design (Snedecor and Cochran, 1980) with levels of Ca, NPP and CC as factors. When the three-way interaction was not found significant, a two-way interaction was undertaken. The effects of individual factors were considered only when the interactions were not significant. Comparisons among means were made by the Duncan Multiple Range test (Duncan, 1955). Contrast analysis was carried out to find out the effect of graded levels of CC on various parameters.

\section{RESULTS}

Body weight gain, feed intake, feed conversion ratio, tibia weight and leg abnormality score were not significantly $(\mathrm{p}>0.05)$ influenced by the three-way interaction among Ca, NPP and CC levels in diet (Table 2). However, these parameters were influenced $(p<0.05)$ by interaction between CC and NPP (weight gain, feed intake and tibia weight) and $\mathrm{CC}$ and $\mathrm{Ca}$ (feed conversion ratio).
The level of CC in diet significantly $(\mathrm{p}<0.05)$ influenced the leg abnormality score. The three-way interaction among these nutrients significantly influenced tibia density, breaking strength, ash content (Table 3), serum $\mathrm{Ca}$ and inorganic P levels and excretion of minerals ( $\mathrm{Ca}, \mathrm{P}, \mathrm{Fe}, \mathrm{Mn}$ $\& \mathrm{Cu}$ ) (Table 4) except $\mathrm{Zn}$, which was affected by the twoway interaction between $\mathrm{Ca}$ and NPP.

\section{Production performance}

Body weight gain and feed intake increased significantly $(\mathrm{p}<0.05)$ by increasing level of CC up to 2,400 ICU $/ \mathrm{kg}$ diet at $0.25 \%$ NPP (Table 2). However, at $0.30 \%$ NPP, improvement in these parameters was observed up to $1,200 \mathrm{ICU} \mathrm{CC} / \mathrm{kg}$ diet. Further increase in the vitamin level did not show any additional benefits on these parameters at both levels of NPP. At $200 \mathrm{ICU} \mathrm{CC} / \mathrm{kg}$, weight gain increased significantly $(\mathrm{p}<0.05)$ due to increase in NPP from 0.25 to $0.30 \%$, however, such an improvement was not observed at higher levels of CC in the $\operatorname{diet}(\geq 1,200 \mathrm{ICU} / \mathrm{kg})$. The levels of $\mathrm{Ca}(0.5 / 0.6 \%)$ tested did not influence body weight gain and feed efficiency. In general, body weight gain, feed intake and feed efficiency improved non-linearly $(p<0.01)$ due to increase in levels of CC in diet. At $0.50 \%$ $\mathrm{Ca}$ in diet, feed efficiency improved significantly with increases in CC to $1,200 \mathrm{ICU} / \mathrm{kg}$, but further increase in CC level to 3,600 ICU significantly $(p<0.05)$ reduced the feed efficiency, which was similar to those fed $200 \mathrm{ICU} \mathrm{CC} / \mathrm{kg}$ diet (Table 2). However, the feed efficiency was not 
Table 3. Tibia mineralization parameters in broiler starter chicks $(21 \mathrm{~d}$ of age $)$ fed different levels of calcium (Ca), non-phytate phosphorus (NPP) and cholecalciferol (CC)

\begin{tabular}{|c|c|c|c|c|c|}
\hline $\mathrm{Ca}(\%)$ & NPP (\%) & $\mathrm{CC}(\mathrm{ICU} / \mathrm{kg})$ & Density $\left(\mathrm{g} \mathrm{cm}^{-3}\right)$ & Breaking strength (N) & $\operatorname{Ash}(g / k g)$ \\
\hline 0.50 & 0.25 & 200 & $0.288^{\mathrm{gh}}$ & $33.9^{\mathrm{c}}$ & $252^{\mathrm{h}}$ \\
\hline 0.50 & 0.25 & 1,200 & $0.340^{\mathrm{fgh}}$ & $36.0^{\mathrm{c}}$ & $287^{\mathrm{g}}$ \\
\hline 0.50 & 0.25 & 2,400 & $0.567^{\text {cde }}$ & $45.9^{\mathrm{abc}}$ & $359^{\mathrm{a}}$ \\
\hline 0.50 & 0.25 & 3,600 & $0.606^{\mathrm{cd}}$ & $47.7^{\mathrm{abc}}$ & $290^{\mathrm{fg}}$ \\
\hline 0.50 & 0.30 & 200 & $0.386^{\text {fgh }}$ & $32.0^{\mathrm{c}}$ & $236^{\mathrm{h}}$ \\
\hline 0.50 & 0.30 & 1,200 & $0.419^{\text {cfgh }}$ & $41.5^{\mathrm{abc}}$ & $313^{\mathrm{de}}$ \\
\hline 0.50 & 0.30 & 2,400 & $0.439^{\text {defg }}$ & $45.5^{\mathrm{abc}}$ & $335^{\mathrm{bc}}$ \\
\hline 0.50 & 0.30 & 3,600 & $0.492^{\text {def }}$ & $55.2^{\mathrm{ab}}$ & $340^{\mathrm{b}}$ \\
\hline 0.60 & 0.25 & 200 & $0.255^{\mathrm{h}}$ & $39.9^{\mathrm{bc}}$ & $251^{\mathrm{h}}$ \\
\hline 0.60 & 0.25 & 1,200 & $0.490^{\mathrm{def}}$ & $42.0^{\mathrm{abc}}$ & $296^{\text {efg }}$ \\
\hline 0.60 & 0.25 & 2,400 & $0.449^{\text {defg }}$ & $44.7^{\mathrm{abc}}$ & $314^{\mathrm{de}}$ \\
\hline 0.60 & 0.25 & 3,600 & $0.481^{\mathrm{def}}$ & $53.5^{\mathrm{ab}}$ & $325^{\text {bcd }}$ \\
\hline 0.60 & 0.30 & 200 & $0.441^{\mathrm{def}}$ & $40.7^{\mathrm{abc}}$ & $253^{\mathrm{h}}$ \\
\hline 0.60 & 0.30 & 1,200 & $0.504^{\text {cdef }}$ & $56.6^{\mathrm{a}}$ & $317^{\mathrm{cd}}$ \\
\hline 0.60 & 0.30 & 2,400 & $0.607^{\mathrm{cd}}$ & $55.3^{\mathrm{ab}}$ & $318^{\mathrm{cd}}$ \\
\hline 0.60 & 0.30 & 3,600 & $0.594^{\text {cd }}$ & $54.1^{\mathrm{ab}}$ & $336^{\mathrm{bc}}$ \\
\hline $\mathrm{n}$ & & & 7 & 7 & 6 \\
\hline $\mathrm{SEM} \pm$ & & & 0.0182 & 1.10 & 0.38 \\
\hline \multicolumn{6}{|c|}{ Mean sum of squares } \\
\hline $\mathrm{Ca}$ & & & 0.018 & $729.1^{*}$ & 1.990 \\
\hline NPP & & & $1.112 * *$ & 493.8 & $8.797 *$ \\
\hline Ca×NPP & & & 0.005 & 103.3 & 2.680 \\
\hline \multicolumn{6}{|l|}{$\mathrm{CC}$} \\
\hline Linear & & & $0.180 * *$ & 40.91 & $793.8 * *$ \\
\hline Non-linear & & & $0.163^{* *}$ & 286.4 & $65.6^{* *}$ \\
\hline $\mathrm{Ca} \times \mathrm{CC}$ & & & $0.081 * *$ & $653.6^{* *}$ & $12.84 * *$ \\
\hline $\mathrm{NPP} \times \mathrm{CC}$ & & & $0.145^{* *}$ & 275.5 & $38.88^{* *}$ \\
\hline $\mathrm{Ca} \times \mathrm{NPP} \times \mathrm{CC}$ & & & 0.526 & $657.3^{* *}$ & $23.00 * *$ \\
\hline Error & & & 0.015 & 131.6 & 1.477 \\
\hline
\end{tabular}

affected due to variation in the $\mathrm{CC}$ level in the diet at $0.60 \%$ Ca.

\section{Leg abnormality score and bone mineralization}

The tibia density, weight and ash content were not increased ( $p>0.05)$ with the level of $\mathrm{Ca}$ in diet from 0.50 to $0.60 \%$, suggesting that the lower level of Ca tested $(0.50 \%)$ was adequate for optimum bone mineralization.

The leg abnormality score progressively and significantly $(\mathrm{p}<0.01)$ reduced $(4.14,2.64$ and 2.28$)$ with each incremental level of $\mathrm{CC}$ up to $2,400 \mathrm{ICU} / \mathrm{kg}$ diet. Increase in $\mathrm{CC}$ level beyond 2,400 ICU/ $\mathrm{kg}$ diet did not further reduce the leg abnormality (2.094). Similarly, leg abnormality score reduced $(\mathrm{p}<0.01)$ significantly $(2.906$ vs. 2.669 ) by increasing the dietary Ca from 0.50 to $0.60 \%$. The NPP levels tested did not influence the magnitude of leg abnormality in broilers.

The two-way interaction between NPP and CC significantly $(p<0.05)$ affected tibia weight (Table 2$)$. The bone weight was significantly lower in groups fed the lowest level of Ca, NPP and CC $(0.5 \%, 0.25 \%$ and 200 $\mathrm{ICU} / \mathrm{kg}$, respectively) compared to those fed $0.60 \% \mathrm{Ca}$,
$0.30 \% \mathrm{NPP}$ and $\mathrm{CC} \geq 2,400 \mathrm{ICU} / \mathrm{kg}$. The bone weight in broilers fed other combinations of these nutrients was intermediate. In general, tibia density decreased and the bone ash content increased non-linearly $(\mathrm{p}<0.01)$, while tibia-breaking strength was not affected by increasing the levels of $\mathrm{CC}$ in diet from 200 to $3,600 \mathrm{ICU} / \mathrm{kg}$ (Table 3). The density and ash content of tibia increased with dietary $\mathrm{CC}$ levels up to $2400 \mathrm{ICU} / \mathrm{kg}$ and further increase in CC level to $3,600 \mathrm{ICU} / \mathrm{kg}$ diet did not show any improvement. Though, the tibia breaking strength increased with $\mathrm{CC}$ level in diet, the difference was not significant at different $\mathrm{Ca}$ and NPP levels tested, except at $0.50 \% \mathrm{Ca}$ and $0.30 \% \mathrm{NPP}$, where the tibia breaking strength was significantly $(\mathrm{p}<0.01)$ higher at 3,600 ICU $/ \mathrm{kg}$ compared to $200 \mathrm{ICU} \mathrm{CC} / \mathrm{kg}$ diet.

\section{Serum Ca and inorganic $\mathbf{P}$}

At all combinations of $\mathrm{CC}$ and $\mathrm{Ca}$ tested, the serum $\mathrm{Ca}$ concentration increased significantly $(\mathrm{p}<0.01)$ by increasing dietary NPP content from 0.25 to $0.30 \%$ (Table 4 ). The concentration of serum $\mathrm{Ca}$ was maximum (16.68 to 17.33 $\mathrm{mg} / \mathrm{kg}$ ) in broilers fed $0.60 \% \mathrm{Ca}$ and $0.30 \% \mathrm{NPP}$ when compared to those fed other combinations of these two 
Table 4. Serum $\mathrm{Ca}$ and inorganic $\mathrm{P}$ and mineral concentration in excreta of broiler starter chicks ( $21 \mathrm{~d}$ of age) fed different levels of calcium (Ca), non-phytate phosphorus (NPP) and cholecalciferol (CC)

\begin{tabular}{|c|c|c|c|c|c|c|c|c|c|c|}
\hline \multirow{3}{*}{$\mathrm{Ca}(\%)$} & \multirow{3}{*}{$\begin{array}{l}\text { NPP } \\
(\%)\end{array}$} & \multirow{3}{*}{$\begin{array}{c}\mathrm{CC} \\
(\mathrm{ICU} / \mathrm{kg})\end{array}$} & \multicolumn{2}{|c|}{ Serum $(\mathrm{mg} / \mathrm{dl})$} & \multicolumn{6}{|c|}{ Excreta } \\
\hline & & & \multirow{2}{*}{$\mathrm{Ca}$} & \multirow{2}{*}{$\mathrm{P}$} & $\mathrm{Ca}$ & $\mathrm{P}$ & $\mathrm{Zn}$ & $\mathrm{Fe}$ & $\mathrm{Mn}$ & $\mathrm{Cu}$ \\
\hline & & & & & \multicolumn{2}{|c|}{$\% \mathrm{DM}$} & \multicolumn{4}{|c|}{$\mathrm{mg} / \mathrm{kg}$ dry matter } \\
\hline 0.50 & 0.25 & 200 & $14.43^{\mathrm{ef}}$ & $4.88^{\text {hi }}$ & $1.205^{\mathrm{g}}$ & $0.853^{\mathrm{e}}$ & 279 & $1,735^{\mathrm{j}}$ & $376^{1}$ & $37.3^{\mathrm{cd}}$ \\
\hline 0.50 & 0.25 & 1,200 & $11.17^{\mathrm{g}}$ & $4.98^{\mathrm{gh}}$ & $1.505^{\mathrm{e}}$ & $0.785^{\mathrm{hi}}$ & 316 & $1,656^{\mathrm{n}}$ & $382^{\mathrm{k}}$ & $38.0^{\mathrm{bc}}$ \\
\hline 0.50 & 0.25 & 2,400 & $14.48^{\mathrm{ef}}$ & $7.19^{\mathrm{b}}$ & $2.065^{\mathrm{b}}$ & $0.740^{1}$ & 320 & $1,788^{\mathrm{f}}$ & $341^{\circ}$ & $36.1^{\mathrm{d}}$ \\
\hline 0.50 & 0.25 & 3,600 & $11.44^{\mathrm{g}}$ & $7.38^{\mathrm{a}}$ & $2.175^{\mathrm{a}}$ & $0.752^{\mathrm{k}}$ & 282 & $1,660^{\mathrm{m}}$ & $392^{1}$ & $39.2^{\mathrm{ab}}$ \\
\hline 0.50 & 0.30 & 200 & $15.87^{\mathrm{d}}$ & $3.72 \mathrm{i}$ & $1.730^{\mathrm{c}}$ & $0.932^{\mathrm{c}}$ & 237 & $1,846^{\mathrm{e}}$ & $466^{\mathrm{c}}$ & $36.0^{\mathrm{d}}$ \\
\hline 0.50 & 0.30 & 1,200 & $16.50_{\mathrm{c}}$ & $4.84^{\mathrm{i}}$ & $1.395^{\mathrm{f}}$ & $0.810^{\mathrm{g}}$ & 216 & $1,651^{\circ}$ & $422^{\mathrm{g}}$ & $31.0^{\mathrm{g}}$ \\
\hline 0.50 & 0.30 & 2,400 & $16.12^{\mathrm{cd}}$ & $5.01^{\mathrm{g}}$ & $1.407^{\mathrm{f}}$ & $0.781^{\mathrm{i}}$ & 282 & $1,786^{\mathrm{g}}$ & $427^{\mathrm{f}}$ & $37.0^{\mathrm{cd}}$ \\
\hline 0.50 & 0.30 & 3,600 & $17.33^{\mathrm{a}}$ & $5.85^{\mathrm{e}}$ & $1.493^{\mathrm{e}}$ & $0.760^{\mathrm{j}}$ & 203 & $1,692^{1}$ & $372^{\mathrm{m}}$ & $31.3^{\mathrm{fg}}$ \\
\hline 0.60 & 0.25 & 200 & $14.73^{\mathrm{e}}$ & $4.92^{\text {ghi }}$ & $1.255^{\mathrm{g}}$ & $0.990^{\mathrm{a}}$ & 232 & $1,770^{1}$ & $445^{\mathrm{d}}$ & $34.0^{\mathrm{e}}$ \\
\hline 0.60 & 0.25 & 1,200 & $10.34^{\mathrm{h}}$ & $3.91^{\mathrm{k}}$ & $1.740^{\mathrm{c}}$ & $0.945^{\mathrm{b}}$ & 264 & $1,722^{\mathrm{k}}$ & $387^{\mathrm{j}}$ & $32.5^{\mathrm{f}}$ \\
\hline 0.60 & 0.25 & 2,400 & $11.43^{\mathrm{g}}$ & $4.38^{\mathrm{j}}$ & $1.520^{\mathrm{e}}$ & $0.840^{\mathrm{f}}$ & 291 & $1,926^{\mathrm{b}}$ & $443^{\mathrm{e}}$ & $36.6^{\mathrm{cd}}$ \\
\hline 0.60 & 0.25 & 3,600 & $13.98^{\mathrm{f}}$ & $3.83^{\mathrm{k}}$ & $1.610^{\mathrm{d}}$ & $0.885^{\mathrm{d}}$ & 286 & $1,767^{\mathrm{I}}$ & $368^{\mathrm{n}}$ & $34.5^{\mathrm{e}}$ \\
\hline 0.60 & 0.30 & 200 & $17.09^{\mathrm{ab}}$ & $4.84^{\mathrm{i}}$ & $1.710^{\mathrm{c}}$ & $0.985^{\mathrm{a}}$ & 277 & $1,734^{\mathrm{j}}$ & $485^{\mathrm{b}}$ & $36.3^{\mathrm{d}}$ \\
\hline 0.60 & 0.30 & 1,200 & $16.68^{\mathrm{bc}}$ & $5.58^{\mathrm{f}}$ & $1.073^{\mathrm{h}}$ & $0.942^{\mathrm{b}}$ & 261 & $1,865^{\mathrm{d}}$ & $490^{\mathrm{a}}$ & $34.0^{\mathrm{e}}$ \\
\hline 0.60 & 0.30 & 2,400 & $17.14^{\mathrm{ab}}$ & $6.04^{\mathrm{d}}$ & $1.410^{\mathrm{f}}$ & $0.849^{\mathrm{e}}$ & 290 & $1,997^{\mathrm{a}}$ & $442^{\mathrm{e}}$ & $39.5^{\mathrm{a}}$ \\
\hline 0.60 & 0.30 & 3,600 & $17.33^{\mathrm{a}}$ & $6.37^{\mathrm{c}}$ & $1.425^{\mathrm{f}}$ & $0.790^{\mathrm{h}}$ & 255 & $1,879^{\mathrm{c}}$ & $396^{0}$ & $31.1^{\mathrm{g}}$ \\
\hline $\mathrm{N}$ & & & 6 & 4 & 4 & 4 & 4 & 4 & 4 & 4 \\
\hline $\mathrm{SEM} \pm$ & & & 0.245 & 0.135 & 0.055 & 0.012 & 6.85 & 12.27 & 5.411 & 0.35 \\
\hline \multicolumn{11}{|c|}{ Mean sum of squares } \\
\hline $\mathrm{Ca}$ & & & $0.714 *$ & $3.99 * *$ & 0.380 & $0.092 * *$ & 127 & $179,474 * *$ & $19,283 * *$ & $13.66^{* *}$ \\
\hline NPP & & & $385.3 * *$ & $0.152 * *$ & 0.371 & $0.036^{* *}$ & $1,5266^{*}$ & $10,070 * *$ & $9,691 * *$ & $40.94 * *$ \\
\hline $\mathrm{Ca} \times \mathrm{N}$ & & & $4.463 * *$ & $29.19 * *$ & 0.048 & $0.051 * *$ & $1,8364^{*}$ & $1,225 * *$ & $5,156^{* *}$ & $95.14 * *$ \\
\hline $\mathrm{CC}$ & & \multicolumn{9}{|c|}{ NS } \\
\hline Linea & & & 0.029 & $0.266^{* *}$ & $0.501^{*}$ & $0.085 * *$ & & $6049 * *$ & $8,917 * *$ & $4.353 * *$ \\
\hline Non-1 & & & $22.17 * *$ & $9.043 * *$ & 0.059 & $0.051 * *$ & & $101,586^{* *}$ & $8,037 * *$ & $63.77 * *$ \\
\hline $\mathrm{Ca} \times \mathrm{C}$ & & & $6.242 * *$ & $3.287 * *$ & 0.108 & $0.005^{*}$ & 1,211 & $37,931 * *$ & $385 * *$ & $11.65^{* *}$ \\
\hline $\mathrm{NPP} \times$ & & & $16.50 * *$ & $1.669 * *$ & $0.651^{* *}$ & $0.026 * *$ & 2,856 & $8418^{* *}$ & $14,131 * *$ & $44.21 * *$ \\
\hline $\mathrm{Ca} \times \mathrm{N}$ & & & $10.94 * *$ & $2.204 * *$ & $0.466^{*}$ & $0.027 * *$ & 846 & $22,721 * *$ & $5,110 * *$ & $7.17 * *$ \\
\hline Error & & & 0.133 & 0.003 & 0.144 & 0.001 & 2,580 & 0.576 & 0.818 & 0.492 \\
\hline
\end{tabular}

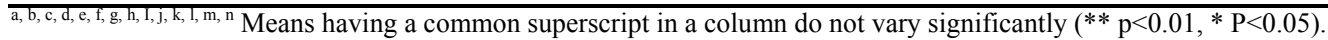

minerals at all levels of CC.

\section{Mineral content in excreta}

In general, the concentration of $\mathrm{Ca}$ in excreta increased linearly $(\mathrm{p}<0.01)$, while the $\mathrm{P}, \mathrm{Fe}, \mathrm{Mn}$ and $\mathrm{Cu}$ decreased non-linearly $(\mathrm{p}<0.01)$ with increase in $\mathrm{CC}$ levels in diet from 200 to 3,600 ICU/kg. Increasing the NPP content from 0.25 to $0.30 \%$ in diet, significantly reduced the Ca content in excreta at all levels of CC except at $200 \mathrm{ICU} / \mathrm{kg}$ (Table 4). At the latter concentration of $\mathrm{CC}, \mathrm{Ca}$ content in excreta increased significantly $(\mathrm{p}<0.01)$ with increase in $\mathrm{P}$ content in diet. At 2,400 and 3,600 ICU CC/kg diet, the Ca content in excreta was significantly $(\mathrm{p}<0.05)$ higher at lower levels of Ca and NPP tested, compared to those fed other levels of these minerals. At $0.25 \% \mathrm{NPP}$ and $0.50 \% \mathrm{Ca}$, the $\mathrm{Ca}$ content in excreta increased significantly with increase in level of $\mathrm{CC}$ up to $3,600 \mathrm{ICU} / \mathrm{kg}$. But, at $0.30 \% \mathrm{NPP}$ and at both the levels of $\mathrm{Ca}$, increasing the $\mathrm{CC}$ level from 200 to $1200 \mathrm{ICU} / \mathrm{kg}$ diet significantly $(\mathrm{p}<0.05)$ decreased the $\mathrm{Ca}$ content in excreta.
The $\mathrm{P}$ content in excreta was significantly $(\mathrm{p}<0.01)$ increased at higher $\mathrm{Ca}$ level compared to those fed low $\mathrm{Ca}$ diet at all levels of $\mathrm{CC}$ except at $200 \mathrm{ICU} / \mathrm{kg}$. At $200 \mathrm{ICU}$ $\mathrm{CC}$ and $0.50 \% \mathrm{Ca} / \mathrm{kg}$ diet, the excreta $\mathrm{P}$ content increased significantly with increase in NPP from $0.25 \%$ to $0.30 \%$ in diet. At $0.60 \% \mathrm{Ca}$, the variation in concentration of $\mathrm{P}$ in diet did not influence the $\mathrm{P}$ content in excreta. In general, the excretion of $\mathrm{P}$ decreased $(\mathrm{p}<0.01)$ non-linearly with increase in $\mathrm{CC}$ level in diet.

The level of Ca, NPP and CC tested did not influence the concentration of $\mathrm{Zn}$ in excreta (Table 4). The concentrations of $\mathrm{Fe}, \mathrm{Mn}$ and $\mathrm{Cu}$ were significantly influenced $(\mathrm{p}<0.01)$ by the three-way interaction among $\mathrm{Ca}$, NPP and CC in diet. The concentrations of Fe and Mn were higher at higher levels of $\mathrm{Ca}$ and NPP in diet. Excretion of $\mathrm{Mn}, \mathrm{Cu}$ and $\mathrm{Fe}$ were maximum at 3,600 ICU CC/kg at 2:1, $\mathrm{Ca}$ and NPP ratio.

\section{Economics}

Reducing the levels of NPP from 0.30 to $0.25 \%$ equals 
to $2.95 \mathrm{~kg}$ dicalcium phosphate per ton of feed, which amounts to $\$ 1.14$ saving for one ton feed. Amount required for additional supplementation of $\mathrm{CC}$ need $\$ 0.33$ per ton of feed. Therefore, by adopting this technology, the cost of boiler starter feed can be reduced to $\$ 0.81$ per ton based on the present cost of $\mathrm{CC}$ and dicalcium phosphate.

\section{DISCUSSION}

The data on body weight gain and feed intake (Table 3) suggest that the levels of NPP can be reduced from 0.30 to $0.25 \%$ in diet, by increasing the CC level to $2,400 \mathrm{ICU} / \mathrm{kg}$. The literature also suggests higher requirement of $\mathrm{CC}$ at sub-optimal levels of $\mathrm{Ca}$ and $\mathrm{P}$ in diet for optimum body weight gain and bone mineralization (Edwards, 1976; Mc Naughton et al., 1977; Baker et al., 1998). A higher level of $\mathrm{CC}$ in the diet is known to stimulate hydrolysis of phytate (Shafey et al., 1991; Mohamed et al., 1991) by increasing the activity of intestinal phytase (Davies et al., 1970; Pointillart et al., 1985), thereby improving the utilization of $\mathrm{PP}$ and $\mathrm{Ca}$.

The levels of Ca and NPP used in the present study were considerably lower than the levels recommended for commercial broiler chicken (NRC, 1994). The recent literature (Vogt, 1992; Sebastian et al., 1996; Sohail and Roland, 1999; Rama Rao et al., 2003a, b) also recommended lower dietary levels of NPP (0.26 to $0.325 \%)$ and $\mathrm{Ca}(0.60$ to $0.76 \%$ ) for broilers (up to $21-35 \mathrm{~d}$ of age) for optimum performance. Better utilization of minerals at their sub optimal levels in the diet might be responsible for obtaining optimum performance at the above levels tested (Rennie et al., 1995; Elliot and Edwards, 1997). Sub optimal levels of Ca and NPP are also known to stimulate the $\mathrm{CC}$ metabolism, which in turn enhances utilization of $\mathrm{Ca}$ and $\mathrm{P}$ (Bar et al., 1978).

The bone mineralization parameters in broilers fed $0.50 \% \mathrm{Ca}$ and $0.25 \% \mathrm{NPP}$ and $2,400 \mathrm{ICU} \mathrm{CC} / \mathrm{kg}$ were either similar (bone density and bone breaking strength, $\mathrm{p}<0.01$ ) or higher (bone ash content, $\mathrm{p}<0.01$ ) compared to those fed the highest levels of these nutrients in the diet $(0.60 \%, 0.30 \%$ and $3,600 \mathrm{ICU} / \mathrm{kg}$, respectively). These results thus indicated that for optimum bone mineralization, $0.50 \% \mathrm{Ca}$ and $0.25 \% \mathrm{NPP}$ were adequate in broiler starter chicks fed diet containing 2,400 ICU CC/kg.

The severity of leg abnormality decreased $(\mathrm{p}<0.05)$ with increase in CC from 200 to 2,400 ICU/kg diet. Increasing dietary $\mathrm{CC}$ content significantly improved weight and ash content of tibia at majority of $\mathrm{Ca}(\mathrm{p}<0.01)$ and NPP $(p<0.05)$ levels tested. Increased tibia density with increase in levels of CC also support the reduced incidence $(p<0.01)$ of leg abnormalities with increasing $\mathrm{CC}$ concentration in diet.
The lack of response to variation in Ca and NPP levels on tibia mineralization parameters at the higher level of CC $(2,400 \mathrm{ICU} / \mathrm{kg}$ diet) tested (Table 3) suggest adequacy of lower concentrations of $\mathrm{Ca}$ and NPP tested for bone mineralization at $2,400 \mathrm{ICU} \mathrm{CC} / \mathrm{kg}$ diet. Increasing the levels of CC up to $2,400 \mathrm{ICU} / \mathrm{kg}$ diet reduced $(\mathrm{p}<0.05)$ the incidence of leg abnormality and increased body weight gain similar to those fed the highest levels of Ca, NPP and $\mathrm{CC}(0.6 \%, 0.3 \%$ and $3.600 \mathrm{ICU} \mathrm{CC} / \mathrm{kg}$ diet, respectively). On the contrary, Cruickshank and Sim (1987) and Lofton and Soares (1986) reported higher incidence of leg abnormality at higher levels of CC (800 to 4,000 ICU $/ \mathrm{kg}$ ) in diets containing recommended levels of $\mathrm{Ca}$ and P. Lack of such ill effects at higher levels of $\mathrm{CC}$ used in the present study on leg abnormality may be due to the sub-optimal levels of Ca and NPP used in the present study. At optimal levels of Ca and NPP (1.0 and $0.45 \%$, respectively), the surfeit levels of $\mathrm{CC}$ in diet might have exerted toxic effects through hypercalcemia and hyper phosphatemia. Similarly, other authors (Waldroup et al., 1965; Meixner et al., 1979; Biehl and Baker, 1997; Baker et al., 1998) have also reported beneficial effects of supplementing higher levels of $\mathrm{CC}$ on broiler performance when fed sub optimal levels of $\mathrm{Ca}$ and $\mathrm{P}$.

In general, the serum $\mathrm{P}$ level increased significantly $(\mathrm{p}<0.01)$ by increasing the level of $\mathrm{CC}$ at all combinations of $\mathrm{Ca}$ and NPP tested, except at $0.60 \% \mathrm{Ca}$ and $0.25 \%$ NPP. The concentration of $\mathrm{P}$ in serum was significantly increased irrespective of $\mathrm{CC}$ level when the ratio between $\mathrm{Ca}$ and NPP was 2:1 compared to those fed disproportionate ratios ( $>$ or $<2$ ) of these minerals. Better utilization and absorption of $\mathrm{Ca}$ and $\mathrm{P}$ at 2:1 ratio (Underwood, 1981; Georgievskii et al., 1982; Rama Rao et al., 2003a; 2006) might have resulted in higher concentrations of these minerals in serum.

The higher levels of NPP and CC in the diet might have a beneficial effect on the utilization of $\mathrm{Ca}$ and $\mathrm{P}$, respectively, as reflected in higher concentrations of the respective mineral in serum (Table 4). Reduced excretion of $\mathrm{Ca}$ with increase in dietary NPP level suggested better utilization of $\mathrm{Ca}$ at lower $\mathrm{Ca}$ and NPP ratio and at $\mathrm{CC} \geq$ $1,200 \mathrm{ICU} / \mathrm{kg}$ diet. Supplementing additional levels of CC might have increased the utilization of dietary $\mathrm{P}$, which was evident in reduced the mineral content in excreta. Reduced excretion of $\mathrm{P}$ in birds fed metabolites of $\mathrm{CC}$ was also reported (Biehl and Baker, 1997). At sub optimal levels of $\mathrm{CC}$, the utilization of $\mathrm{Ca}$ might be lower and further increase in NPP resulted in wider Ca and NPP ratio with a consequent rise in excretion of $\mathrm{Ca}$ (Table 4), perhaps due to formation of calcium phosphate in the gut.

Excretion of $\mathrm{Fe}$ and $\mathrm{Mn}$ was higher at higher levels of $\mathrm{Ca}$ and or NPP in diet, probably due to inhibitory effect of these minerals on absorption of trace minerals (Underwood, 
1981; Georgievskii, 1982). The concentration of $\mathrm{Fe}, \mathrm{Cu}$ and $\mathrm{Mn}$, particularly at the highest level of CC $(3,600 \mathrm{ICU} / \mathrm{kg})$ showed maximum excretion at $2: 1 \mathrm{Ca}$ and NPP ratio, contradicting the popular assumption of $2: 1$ as the ideal $\mathrm{Ca}$ and NPP ratio for mineral utilization. At 2:1 Ca and NPP ratio, the utilization of these two minerals in chicken is known to be maximum and therefore, the possibility of their interference with utilization of trace minerals was less at 2:1 $\mathrm{Ca}$ and $\mathrm{P}$ ratio (NRC, 1980). The contradictory findings of the present study may be due to the sub-optimal levels of $\mathrm{Ca}$ and NPP used in the present study. The literature indicates increased utilization of trace minerals (Baker and Halpin, 1988; Biehl et al., 1995) with CC metabolites in diet. However, further studies are required to determine the specific effect of varied levels of $\mathrm{Ca}$ and NPP on trace mineral utilization.

Based on the results, it could be concluded that the dietary NPP levels can be reduced from 0.30 to $0.25 \%$ without affecting the weight gain, leg abnormality score, bone mineralization and mineral retention at $0.50 \% \mathrm{Ca}$ by increasing dietary $\mathrm{CC}$ to $2,400 \mathrm{ICU} / \mathrm{kg}$ diet with a net saving of $\$ 0.81$ per ton of feed. Excretion of $\mathrm{P}$ and $\mathrm{Mn}$ also decreased at 2,400 ICU/kg diet than at $200 \mathrm{ICU} / \mathrm{kg}$ diet.

\section{ACKNOWLEDGEMENT}

The authors wish to acknowledge the financial support extended for conducting this study by the Indian Council of Agricultural Research, New Delhi, India under the Young Scientist Award Scheme.

\section{REFERENCES}

AOAC (Association of Official Analytical Chemist). 1990. Official Methods of Analysis of the Association of Official Analytical Chemists (Virginia, USA., Association of Official Analytical Chemists).

Baker, D. H. and K. M. Halpin. 1988. Zinc antagonizing effect of fish-meal, wheat bran and a corn soybean meal mixture when added to a phytate - and fibre free casein-dextrose diet. Nutr. Res. 8:213-218.

Baker, D. H., R. R. Biehl and J. L. Emmert. 1998. Vitamin $\mathrm{D}_{3}$ requirement of young chicks receiving diets varying in calcium and available phosphorus. Br. Poult. Sci. 39:413-417.

Bar, A., A. Cohen, S. Edelstein, M. Shemesh, G. Montecuccoli, and S. Hurwitz. 1978. Involvement of cholecalciferol metabolism in birds in the adaptation of calcium absorption to the needs during reproduction. Comparative Biochem. Phys. 59:245-249.

Biehl, R. R. and D. H. Baker. 1997. Utilization of phytate and nonphytate phosphorus in chicks as affected by source and amount of vitamin $\mathrm{D}_{3}$. Anim. Sci. 75:2986-2993.

Biehl, R. R., D. H. Baker and H. F. Deluca. 1995. 1 $\alpha$-hydroxylated cholecalciferol compounds act additively with microbial phytase to improve phosphorus, zinc and manganese utilization in chicks fed soy-based diets. J. Nutr. 125:24072416.

Cruickshank, J. J. and J. S. Sim. 1987. Effects of excess vitamin D3 and cage density on the incidence of leg abnormalities in broiler chickens. Avian-Dis. 31:332-338.

Davies, M. I., G. M. Ritcey and I. Motzok. 1970. Intestinal phytase and alkaline phosphatase of chicks: influence of dietary calcium, inorganic and phytic phosphorus and vitamin $\mathrm{D}_{3}$. Poult. Sci. 49:1280-1286.

Duncan, D. B. 1955. Multiple range and multiple $F$ tests. Biometrics 11:1-55.

Edwards Jr. H. M. 1976. A re-examination of the nutritional role of vitamin D. Proc. Georgia Nutr. Conf. pp. 77-83.

Edwards Jr. H. M., R. B. Shirley, W. B. Escoe and G. M. Pesti. 2002. Quantitative evaluation of 1- $\alpha$-hydroxycholecalciferol as a cholecalciferol substitute for broilers. Poult. Sci. 81:664-669.

Elliot, M. A. and H. M. Edwards Jr. 1997. Effect of 1,25dihydroxycholecalciferol, cholecalciferol, and fluorescent lights on the development of tibial dyschondroplasia and rickets in broiler chickens. Poult. Sci. 76:570-580.

Fiske, H. and Y. Subba Row. 1925. The colorimetric determination of phosphorus. J. Biolog. Chem. 66:375-400.

Georgievskii, V. I. 1982. The physiological role of macroelements. In: Mineral Nutrition of Animals. (Ed. V. I. Georgievskii, B. N. Annenkov, V. I. Samokhin). 1982. Butterworths, London.

Haugh, H. and H. J. Lantzsch. 1983. Sensitive method for the rapid determination of phytate in cereals and cereal products. J. Sci. Food Agric. 34:1423.

Kornegay, E. T., D. M. Denbow, Z. Yi and V. Ravindran. 1996. Response of broilers to graded levels of microbial phytase added to maize-soybean meal-based diets containing three levels of nonphytate phosphorus. Br. J. Nutr. 75:839-852.

Lofton, J. T. and J. H. Soares Jr. 1986. The effects of vitamin $\mathrm{D}_{3}$ on leg abnormalities in broilers. Poult. Sci. 65:749-756.

Mc Naughton, J. L., E. J. Day and B. C. Dilworth. 1977. The chick's requirement for 25-hydroxycholecalciferol and cholecalciferol. Poult. Sci. 56:511-516.

Meixner, B., H. Jeroch and H. J. Eisengarten. 1979. Analysis of the vitamin $\mathrm{D}_{3}$ supply of broilers. Monatshefte-furVeterinarmedizin 34(17):655-657.

Mohamed, A., M. J. Gibney and T. G. Taylor. 1991. The effects of dietary levels of inorganic phosphorus, calcium and cholecalciferol on the digestibility of phytate-P by the chick. Br. J. Nutr. 66:251-259.

National Research Council. 1994. Nutrient requirements of poultry, $9^{\text {th }}$ revised edition. Nutrient requirements of domestic animals. National Research Council, National Academy Press, Washington, DC.

NRC. 1980. Mineral Tolerance of Domestic Animals. National Academy of Sciences-National Research Council, Washington, DC.

Paik, I. K. 2000. Nutritional management for environment friendly animal production. Asian-Aust. J. Anim. Sci. 13(Special Issue):302-314.

Park, S. W., H. Namkung, H. J. Ahn and I. K. Paik. 2005. Enrichment of vitamin D3, $\mathrm{K}$ and iron in eggs of laying hens. Asian-Aust. J. Anim. Sci. 18:226-229.

Pointillart, A., A. Fourdin, M. Thomasset and M. E. Jay. 1985. Phosphorus utilization, intestinal phosphatase and hormonal 
control of calcium metabolism in pigs fed phytic phosphorus; soybean or rapeseed diets. Nutr. Report Inter. 32:155-167.

Qian, H., E. T. Kornegay and D. M. Denbow. 1997. Utilization of Phytate phosphorus and calcium as influenced by microbial phytase, cholecalciferol, and the calcium: total phosphorus ratio in broiler diets. Poult. Sci. 76:37-46.

Rama Rao, S. V., A. K. Panda, M. V. L. N. Raju, G. Shyam Sunder and N. K. Praharaj. 2003b. Requirement of Calcium for commercial broilers and White Leghorn layers at low dietary phosphorus levels. Anim. Feed Sci. Tech. 106:199-208.

Rama Rao, S. V., M. V. L. N. Raju, M. R. Reddy, G. Shyam Sunder and P. Pavani. 2003a. Dietary calcium and non-phytin phosphorus interaction on growth bone mineralization and mineral retention in broiler starter chicks. Asian-Aust. J. Anim. Sci. 16:719-725.

Rama Rao, S. V., M. V. L. N. Raju, M. R. Reddy and P. Pavani. 2006. Interaction between dietary calciumand non-phytate phosphorus levels on growth, bone mineralization and mineral excretion in commercial broilers. Anim. Feed Sci. Tech. (in press).

Rennie, J. S., H. A. McCormack, C. Farquharson, J. L. Berry, E. B. Mawer and C. C. Whitehead. 1995. Interaction between dietary 1,25-dihydroxycholecalciferol and calcium and effects of management on the occurrence of tibial dyschondroplasia, leg abnormalities and performance in broiler chickens. Br. Poult. Sci. 36:465-477.

Sebastian, S., S. P. Touchburn, E. R. Chavez and P. C. Lague. 1996. Efficacy of supplemental microbial phytase at different dietary calcium levels on growth performance and mineral utilization of broiler chickens. Poult. Sci. 75:1516-1523.
Shafey, T. M., M. W. McDonald and J. G. Dingle. 1991. Effects of dietary calcium and available phosphorus concentration on digesta $\mathrm{pH}$ and on the availability of calcium, iron, magnesium and zinc from the intestinal contents of meat chicken. Br. Poult. Sci. 32:185-194.

Shafey, T. M., M. W. Mcdonald and R. A. E. Pym. 1990. Effects of dietary calcium, available phosphorus and vitamin $\mathrm{D}$ on growth rate, food utilization, plasma and bone constituents and calcium and phosphorus retention of commercial broiler strains. Br. Poult. Sci. 31:587-602.

Snedecor, G. W. and W. G. Cochran. 1980. Statistical Methods. Iowa State University Press, Ames, IA.

Sohail, S. S. and D. A. Roland Sr. 1999. Influence of supplemental phytase on performance of broilers four to six weeks of age. Poult. Sci. 78:550-555.

Underwood, E. J. 1981. Chapter 4: calcium and phosphorus pp 3139. The Mineral Nutrition of Livestock. Second ed., Commonwealth Agricultural Bureaux.

Vogt, H. 1992. Differing calcium and phosphorus content in broiler feeds-ecological aspects on mineral supply. Lohmann Information, July-August: 11-15.

Waldroup, P. W., J. E. Stearns, C. B. Ammerman and R. H. Harms. 1965. Studies on the vitamin $D_{3}$ requirement of the broiler chick. Poult. Sci. 44:543-548.

Wasserman, R. H. and A. N. Taylor. 1973. Intestinal absorption of phosphate in the chicks. Effect of vitamin D and other parameters. J. Nutr. 103:586-599.

Watson, I. T., C. B. Ammerman, S. M. Miller and R. H. Harms. 1970. Biological assay of inorganic manganese for chicks. Poult. Sci. 49:1548-1554. 